\title{
Distinguishing the virtuous city of Alfarabi from that of Plato in light of his unique historical context
}

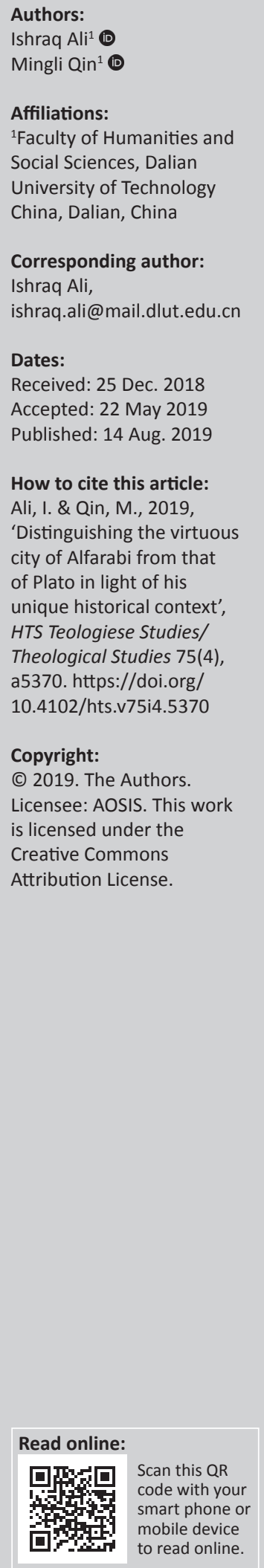

There is a tendency among scholars to identify Alfarabi's political philosophy in general and his theory of the state in particular with that of Plato's The Republic. Undoubtedly Alfarabi was well versed in the philosophy of Plato and was greatly influenced by it. He borrows the Platonic concept of the philosopher king and uses it in his theory of the state. However, we argue that the identification of Alfarabi's virtuous city with that of Plato's The Republic is an inaccurate assessment as it involves overlooking Alfarabi's unique religiopolitical context. Alfarabi was a Muslim political philosopher, and the present article intends to understand Alfarabi's theory of the state in light of his historical context. The article shows that, viewed through the prism of Islamic religion and political history, Alfarabi's virtuous city seems distinct from that of Plato's The Republic.

Keywords: Alfarabi; Plato; the Republic; Virtuous city; Utopia; Religion; Politics.

\section{Introduction}

The Homo sapiens' need for association has long been acknowledged as a fundamental truth. The inherent tendency to form an association is the fundamental characteristic that distinguishes man qua man from animals on one hand and God on the other. However, the search for an ideal mode of association is as old as the history of human association. Dissatisfaction at the social order has prompted the thinkers over centuries to seek an ideal sociopolitical arrangement that can serve as a panacea for all the human problems. Abu Nasr Alfarabi's Mabadi Ara Ahl al-Madina al-Fadhila [Principles of the Opinions of the Inhabitants of the Virtuous City] and Plato's The Republic are two such works that claim to contain the model of an ideal city which can ensure the ultimate human perfection and happiness. ${ }^{1}$

There is a tendency among scholars to relate Alfarabi's political philosophy in general and his theory of the state in particular to that of Plato, especially of The Republic. ${ }^{2}$ One of the most prominent of such scholars is Fakhry (2002:vii) who is of the opinion that Ara is 'inspired by Plato's Republic'. Similarly, Walzer (1991:779) understands that Alfarabi relies on Aristotle for his theoretical philosophy, but 'in political science he preferred to follow Plato's Republic and Laws'. He (Walzer 1985:10) suggests that 'the political section' of Ara is mainly based on an extinct 'commentary on Plato's Republic' that might have been 'written in the sixth century A.D.'. Pines (1963:lxxxvi) in the introduction to his translation of Maimonides' Guide of the Perplexed comments that 'Alfarabi's position, as far as political philosophy is concerned, is largely Platonic'. Rosenthal (1958:114) also acknowledges that Alfarabi has 'drawn upon' Aristotle's Nicomachean Ethics, but considers his political philosophy as mainly influenced by Plato. Similarly, Marmura (2005:398) argues that Alfarabi's metaphysics, epistemology and psychology are largely Aristotelian and Neoplatonic, while his theory of the state is Platonic. There is no doubt that the major works of Plato, including The Republic, were available to Alfarabi and he was fully conversant with them. He viewed the philosophy of Plato as the true philosophy and followed The Republic by treating 'the whole of philosophy proper within a political framework' in his major political writings, including Ara (Strauss 1945:358-359). Most importantly, he borrowed the Platonic idea of a perfect

1.There are multiple writings of Alfarabi, such as The Political Regime and The Attainment of Happiness, that deal with the Platonic theme of the best city and contend for a comparison with the works of Plato. However, the present article mainly focuses on Alfarabi's Mabadi Ara Ahl al-Madina al-Fadhila and Plato's The Republic. Other works of Alfarabi are occasionally referred to for the explanatory purpose. Abu Nasr Alfarabi and Mabadi Ara Ahl al-Madina al-Fadhila are hereafter referred to as Alfarabi and Ara, respectively.

2.Political philosophy deals, at the most abstract level, with the fundamental questions related to the communal or social life of human beings. It tries to find answers to the fundamental questions such as who should exercise authority; what are the principles for the justification of political authority; what should be the rights and duties of the members of the society and why; what is the nature, origin and purpose of government and what goals a political community should try to achieve and why. Explaining the meaning of the word 'political' itself is also one of the important concerns of political philosophy. The topics that the political philosophy discuss include justice, freedom, liberty, utopia, human nature, rights, duties, social control, peace, war and so on. Some philosophers incorporate metaphysics, economics or ethics in their political philosophy. The theory of the state of a particular philosopher, on the other hand, is a framework for the implementation of his political philosophy. 
state ruled by a philosopher king. No one denies the Platonic influence on Alfarabi and there are certain obvious Platonic elements in his political philosophy in general and the theory of the state in particular, but the question that deserves consideration is how much Alfarabi's virtuous city and its philosopher king resembles that of Plato's The Republic?

Although the political thought of Alfarabi is extensively investigated in relation to its Greek ancestry, very few systematic attempts are made to understand it in light of its historical context. There are some scholars, such as Tabatabai (1994:121), Al-Jabri (2000:236) and Fairahi (2003:326), who understand the virtuous city of Ara as a product of a reaction to the sociopolitical crisis of Alfarabi's time, the Abbasid era. However, the sociopolitical crisis of Alfarabi's time is a small part of the broad religiopolitical context that spanned around three centuries prior to Alfarabi. It starts with the religion Islam and the unification of spiritual and political authority in one person, Muhammad, who established the city-state of Medina, a model for Muslims till this day. The present article intends to understand Alfarabi's theory of the state in light of its broader religiopolitical context and shows that, viewed through the prism of the peculiar historical context, Alfarabi's utopia seems distinct from that of Plato's The Republic.

\section{Alfarabi's historical context}

Because Islam, like Judaism and unlike Christianity, was fashioned in a lawless desert, the revelations became the only and exclusive law of the Muslims covering spiritual as well as temporal and political matters (Melamed 2003:3). Thus, we see a unification of spiritual and political authority in Islam as Muhammad was not only the spiritual but also the political leader of the Muslims. He established the city-state of Medina and Muslims, even to this day, revere and treat the Medina state under the leadership of Muhammad as an ideal, a model to follow and a kind of utopia that is dreamt of.

The first problem that the Muslim polity faced after the death of Muhammad was related to succession. Quran and the words and actions of the prophet were the two sources of guidance for the Muslims after the death of Muhammad, but both contained no explicit provision about succession. Thus, the first conflict in Islam, the religiopolitical unity, was not 'about the nature of the divine, but about who should lead and how the leader should be appointed' (Black 2011:14-15). The conflict divided Muslims into Sunni and Shia, a division that exists even today and stemmed from a difference of opinion on the criteria for the selection of caliph.

The companions of Muhammad chose Abu Bakr as his successor and the first caliph of Muslims through consultation (Shura). However, a group of Muslims contested the legitimacy of Abu Bakr as the successor of Muhammad and regarded Ali ibn Abi Talib, Muhammad's cousin and son-in-law, as the rightful leader of the Muslims on the grounds that he had been designated by Muhammad himself as his successor. The supporters of Ali came to be known as
Shias who hold that since God designates prophets, it is only God who designates the successors of a prophet and the people of the community have no right and no say in this matter and that Ali was designated by God through the prophet Muhammad as his successor. On the contrary, the majority group, Sunnis, in light of a number of hadiths (sayings of the Prophet), emphasise the importance of consultation as the proper procedure for making important community decisions including the selection of leader and argue that the Prophet nominated no successor as he expected the Muslims to choose one after him through consultation. Sunnis regard Abu Bakr (First), Umar ibn Khattab (Second), Uthman ibn Affan (Third) and Ali (Fourth) as the four legitimate and rightly guided caliphs of the Muslims in the given order, whereas Shia deny the legitimacy of the first three caliphs and consider Ali as the only legitimate successor of the Prophet Muhammad. According to the Shiite view, 'the Leadership (Imama) belonged to whichever of Muhammad's direct biological descendants ... had been designated by his predecessor' (Black 2011:16).

Although a difference of opinion existed among Muslims on the question of leadership, they were not involved in an armed confrontation until the first Muslim civil war (AD 656-661), known as the First Fitna, that took place after the assassination of Uthman and the nomination of Ali as the fourth caliph of Muslims. Muawiya Abu Sufyan (a relative of Uthman), Aisha bint Abu Bakr (the widow of Muhammad) and some of the companions of the Prophet, among whom Talhah ibn Ubaydullah and Zubayr ibn al-Awam were the most prominent, demanded vengeance on Uthman's death but seeing Ali reluctant, revolted against him. Ali defeated Aisha and her allied companions of the Prophet in the 'battle of the camel' (AD 656) near Basra and then turned towards Muawiya, who, at the battle of Siffin (AD 657), reached an agreement with Ali to settle the issue through arbitration. Some of Ali's hard-line Shia supporters, who were later known as Kharijites (those who walk out), broke away from him and condemned him 'for subjecting his entitlement to human arbitration' (Black 2011:16). It was one of these Kharijites who assassinated Ali in AD 661 which marks the end of the 'First Fitna'. Muawiya, who had already claimed caliphate in AD 660, was endorsed by Ali's son, Hasan, after his father's death. Although the Shia-Sunni rift continued, a kind of political stability was restored. However, Muawiya appointed his son, Yazid, as his successor, thereby converting caliphate into a hereditary office. In this way, he became the founder of Umayyad dynasty (AD 661-750).

The Muslim empire went through an unprecedented expansion during the Umayyad period and became one of the largest empires stretching from Spain in the west to the border of present-day China in the east. The ever existing threat of civil war and the huge size of the empire composed of people with diverse religious, social, cultural and political views asked for an absolutist strong centralised government, the model of which was provided by the Sasanian empire. The Umayyads developed patrimonial monarchy which was a blend of 
Arabo-Islamic ways with the 'monarchical ideas and practice taken over from conquered Iran' (Black 2011:18). The caliph's authority could neither be restricted nor questioned and he was allowed to assume the role of religious legislator, a role previously fulfilled by the Prophet.

From the very onset, Umayyad rule faced opposition. The conversion of caliphate into hereditary and dynastic rule was resisted especially by Hussain, the younger son of Ali, who rebelled and got killed by Yazid's forces in the battle of Karbala and Shia never accepted Umayyads as the legitimate rulers. Hereditary lineage with the ruler being the criterion for succession, some incompetent and ineligible persons, such as Yazeed, Yazeed II and Waleed II, became rulers who lacked the capacity and vision to effectively rule such a huge empire. They were more inclined towards pleasure and physical gratification as opposed to asceticism demanded by the religion. The Ulama (Religious Scholars) viewed them as impious and deviant from the path of Islam that earned them a negative sentiment and diminishing popularity among the masses. The multiple unsuccessful attempts to conquer Constantinople dented their military might. Above all, there was an obvious conflict between the Arab tribal ideas of authority and the concept of strong centralised authority necessary for keeping the huge empire intact. Equally damaging was the resentment among the non-Arab converts as they saw that Umayyads were more inclined towards Arabs and Arab ways and that they were ignored, deprived and unjustly treated in spite of the fact that they belonged to an older and superior culture than that of Arabs. There were a variety of religious and social schools of thought in the huge Umayyad empire, each with a different understanding of society and government with different political implications. These were some of the factors that ultimately led to the inevitable fall of Umayyads and the rise of Abbasids to power in AD 750.

Abbasids rose to power with a promise of harmony, concord, happiness, piety and just rule in accordance with the teachings of Islam. Because they claimed the legitimacy of their rule on the basis of their kinship to Muhammad, the Shia faction welcomed and supported them against Umayyads who did not belong to the family of the Prophet. Their slogan of reforms attracted those resentful of Umayyads' corruption and it was, in fact, a coalition of Shia, Persian Mawali (nonArab Muslims) and Eastern Arabs that Abbasids built to oust Umayyads and install the Abbasid dynasty.

The Abbasid period is known for economic and intellectual vitality. Baghdad, the capital of the Abbasid dynasty, became the world's economic and educational centre under Abbasids. The Arab merchants dominated trade by land and sea between the far west and far east. The Abbasid caliphs, particularly Harun al Rashid and his son al Mamun, patronised arts, sciences and the translation of works from other languages. The great scholars of the time gravitated to Baghdad where al Mamun established Bayt al-hikma (The House of Wisdom), a library-cum-institute that housed prominent Muslim and
non-Muslim scholars who gathered, translated and expanded upon the works from other civilisations. By the time of Alfarabi (AD 870-950), most of the works of Plato, Aristotle and their late Greek commentators had been translated (Black 2011:57).

Although the Muslim empire thrived educationally and economically during Abbasid reign, those who expected a fundamental sociopolitical change met utter disappointment. The succession of al-Mansur as the second Abbasid caliph on the basis of hereditary lineage made it clear that the claimed revolution was nothing more than a replacement of one dynasty with another. The Abbasids who started as reformist revolutionaries not only adopted the autocratic ideas of the patrimonial monarchy of their predecessors, but took it to the next level and perfected it. Soon after coming to power they turned their backs on Shias, the allies who had supported them in the revolution, and tilted towards the majority Sunnis. However, they remained strongly connected to the Persian mawalis. The Persian ideas and practices dominated the Abbasid court and government. Al-Mamun aligned himself with the theologians, particularly Mutazilites, who professed the application of unaided reason to the religion, against the literalists, reporters and Ulama. He established Mihna, an inquisition aimed at forcing the government officials as well as religious leaders 'to accept his religious views and his authority in matters of religious ritual and doctrine' (Lapidus 1975:379). The Ulama and officials were tested and examined in Mihna and those who did not adhere to the Mutazili theology were subjected to severe punishments. The theology was poles apart from the contemporary popular religion and the caliph's adherence to it resulted in a division between the court and the people. The gap between the caliph and the people widened as caliphs surrounded themselves with officials and personal armies. Following the trend initiated by al-Mamun, the caliph al-Mutasim created a personal military force of slaves (Ghilman) that grew in strength and influence with the passage of time, resulting in anger and unrest in Baghdad that forced the caliph to shift the capital to Samarra in AD 836. The caliphs' guards gained strength to the extent that they started killing one caliph and replacing him with another. As the office of the caliph was getting weaker, the provincial governors (Emirs), from the time of al-Mamun onwards, were becoming economically and militarily independent. Although they recognised the Abbasid caliph, some of them, like the governor of Persia, established their own dynasties and ruled as kings.

With the continuously diminishing authority of caliph, the Muslim empire was disintegrating and different territories were breaking off from Abbasid rule. In the last attempt for integration, al-Radi created the position of Amir ul Umara (the Emir of Emirs / Chief Emir) for Iraq's governor, delegating him the supreme authority and control over all the other Emirs. However, the device meant for integration backfired and ended up in the hands of Buyids who used it as hereditary title and became the de facto rulers, leaving the caliph as a 
mere figurehead. By the first half of the 10th century, the Abbasid caliph was nothing more than a nominal religious figure without any effective authority. Alfarabi lived through the decline phase of the Abbasid rule, the time of disintegration, instability and chaos in the Muslim empire.

\section{The virtuous city of Alfarabi and Plato}

Alfarabi was a Muslim philosopher and there can be no doubt that he was fully aware of the three-centuries-old political history of Muslims till his time. The history that is, as we have seen, full of disasters, civil wars, brutal power struggles, incompetent rulers, disappointments for the people, disintegration and chaos. Evidently, all these ills stemmed from the absence of a coherent political philosophy, the failure of Muslims to find answers to the fundamental questions: who should rule and exercise authority; what should be the relation between the ruler and ruled; and what should they try to achieve through association. The political philosophy of Alfarabi, particularly his theory of virtuous city, can be seen as an answer to these questions. For the greater part of his life, Alfarabi lived in Baghdad, the capital of Abbasid caliphate. However, in AD 942, less than a decade before his death, he shifted to Aleppo and became a part of 'the Imami court of the Hamdanids', and it was here that 'he produced his major works on Politics' that contain his theory of virtuous association (Black 2011:61-62). His migration from the Abbasid's capital, joining the court in Aleppo and writing his political works there, have led some scholars to view his theory of the state as a protest against the Abbasid caliphate. While Alfarabi would have been really disappointed with the Abbasids, he would have been equally resentful of the sociopolitical condition of the Muslims before Abbasids and after Muhammad. More than a protest against the Abbasid caliphate, Alfarabi's theory of the state is a reaction to the whole disastrous Muslim political history after the death of Muhammad and a programme to revive the Medinan glory of Prophet Muhammad's time.

Alfarabi enumerates 12 qualifications for the ruler of his virtuous city: (1) soundness of body, (2) accurate understanding, (3) sharp memory, (4) intelligence and quickwittedness, (5) eloquence, (6) love of 'learning and acquiring knowledge', (7) love of 'truth and truthful men', and hatred for 'falsehood and liars', (8) no cravings 'for food and drink and sexual intercourse', and 'aversion to gambling and hatred of the pleasures which these pursuits provide', (9) magnanimity, love of honour and detest for 'everything ugly and base', (10) no interest in money and 'other worldly pursuits', (11) love of 'justice and of just people', and hatred for 'oppression and injustice and those who practice them'; no stubbornness or reluctance if 'asked to do justice', but reluctance if 'asked to do injustice', and (12) bravery and firm resolve in doing the right thing (Alfarabi 1985:247-249). We can see that Alfarabi has incorporated in his list all the attributes of a ruler proposed by Plato in book VI of The Republic. However, there are three qualifications that are peculiar to his list: (1) soundness of body, (2) eloquence and (3) love of justice. These three characteristics drastically distinguish the ruler of Alfarabi from the philosopher king of Plato's The Republic. These are the prerequisites that must be present in a prospective ruler so that because of these characteristics he could be able to perform some specific functions as a ruler. Thus, connected to the three qualifications are three duties peculiar to the ruler of Alfarabi. Firstly, the prospective ruler must have a sound body so that he could be able 'to shoulder the tasks of war' as a ruler (Alfarabi 1985:247). Secondly, he should be eloquent and 'a good orator' so that, as a ruler, he could be 'able to rouse [other people's] imaginations by well-chosen words' (Alfarabi 1985:247). While distinguishing between religion and philosophy, Alfarabi argues that religion is the imitation of philosophy. It is the symbolic representation of the philosophical truth. The things that the philosopher knows, as they are, through demonstration, others know their symbolic representation (religion) through imagination (Alfarabi 1985:279). Thus, in Alfarabi, the ruler should use his eloquence and the skill of oratory to arouse people's imaginations and preach them religion. Thirdly, the qualification of a ruler to love, support and do justice, but hate and abstain from doing injustice seems to highlight his role as a judge in the virtuous city.

Thus, unlike the philosopher king in Plato's The Republic, the ruler of Alfarabi's virtuous city is a warrior, preacher of religion and judge. In Plato's The Republic, the philosopher king does not physically participate in war as this duty is exclusively assigned to the guardians of the city. The role of Plato's philosopher king is restricted to the guidance and supervision of the guardians. Alfarabi identifies the 'war' as holy war (Jihad), a concept obviously unknown to Plato (Alfarabi 1952:113). Plato criticises rhetoric, whereas Alfarabi makes it one of the important conditions for a ruler. Moreover, in Plato, there is no mention of the role of the ruler as a judge.

Fakhry points out that, as Al-Mawardi suggests in his Political Ordinances (Al-Ahkam al Sultaniyah), the three qualifications (soundness of body, eloquence and love of justice) are the part of prerequisites 'specifically' for the office of caliph (Fakhry 2002:105). The first four caliphs, like Muhammad, had sound body, eloquence and love of justice, and they, as rulers, participated in the holy war, preached religion and acted as judge. So, more than a philosopher king, Alfarabi seems to be characterising a caliph after Muhammad as the ruler of his virtuous city. However, Alfarabi's calling the ruler of his virtuous city 'Imam' is meaningful. Scholars are of the opinion that Alfarabi most probably belonged to the Imami Shia faction of Islam which, as we have discussed, recognises Ali rather than the first three caliphs as the rightful successor of Muhammad. Although the first three caliphs before Ali and the two dynasties after him effectively ruled the Muslims as caliphs, Imami Shias recognise a separate line of twelve Imams starting from Ali as the true successors of Muhammad and 
the actual spiritual and political leaders of the Muslims. The eleventh of these Imams, Hasan al-Askari, died in AD 874, and Imamis believe that his successor, Muhammad ibn Hasan al-Mahdi, the twelfth and final Imam, went into hiding which they call Ghaybat al-Sughra (Minor Occultation). According to Imamis, al-Mahdi communicated with his followers through his representatives during the minor occultation, but after the death of the last of these representatives in AD 941, the Imam went into permanent hiding (Ghaybat al-Kubra/Major Occultation), and that he would return when God wishes. They view al-Mehdi as a reflection of Muhammad's character, a messianic figure, a redresser of wrongs, who will return, revive the Muhammadan glory and fill the earth with peace and justice. ${ }^{3}$ Because Alfarabi lived and produced his writings during the hiding of the twelfth Imam, it seems probable that by calling his ruler 'Imam' he is referring to Imam Mehdi as the ruler of his utopian virtuous city.

In Plato as well as Alfarabi, it is the superior knowledge of the ruler that entitles him to the authority as ruler. The knowledge of Plato's philosopher king comes through unaided reason. $\mathrm{He}$, in terms of the cave allegory, ascends to the world of ideas and gains the superior knowledge through reason. On the contrary, the source of Alfarabi's ruler knowledge is reason plus, most importantly, divine revelation (Wahy), associated not with the rational part of the soul but with the imaginative part. Unlike Plato's philosopher king, the ruler of Alfarabi's virtuous city is a philosopher prophet who receives divine revelations. Revelation as his source of knowledge differentiates him from the ruler of Plato's The Republic and associates him with the prophet Muhammad, rightly guided Sunni caliphs and Shia Imams who received guidance from God through revelation. ${ }^{4}$

The impact of Alfarabi's identification of his ruler with Muhammad, Shia Imams and Sunni caliphs can be seen in the sanctity and the elevated role that he assigns to his ruler in his virtuous city. In addition to the role as warrior, preacher and judge, Alfarabi (1985) makes the organisation, rise and the removal of any ill or deficiency of the city dependent on the ruler:

The ruler of this city must come to be in the first instance, and will subsequently be the cause of the rise of the city and its parts and the cause of the presence of the voluntary habits of its parts and of their arrangement in ranks proper to them; and when one part is out of order he provides it with the means to remove its disorder. (p. 235)

3.Sunnis also recognise the coming of Mehdi, a messiah, near the end of time However, while Imamis understand that Imam Mehdi is in hiding, Sunnis believe that he is not yet born.

4.It is important to point out that the revelations received by the prophet Muhammad are distinguished from those of Imams, caliphs or other pious people. The revelations sent to Muhammad included guidance from God on the matters of Din revelations sent to Muhammad included guidance from God on the matters of Din [religion] as well as Dunya [world]. However, religious scholars argue that no addition in the religion is possible after the Quran's explicit announcement of religion's completion during the lifetime of Muhammad. Therefore, after Muhammad, people, on the basis of their piety, can receive guidance from God only about the worldly matters that do not make any change to the religion. This guidance is ranked as an inferior subdivision of the wahy received by the Prophe Muhammad and recognised as Ilham, Wahy Tasdeed, Wahy Tadeeb and so on.
In The Republic, the violation of laws related to birth leads to the 'dissolution' of Plato's ideal city (Plato 1991:224-225). Alfarabi (1985:253), on the contrary, suggests that his virtuous city will perish after remaining kingless for a certain time. Thus, the perishing of Alfarabi's city, unlike that of Plato, is linked to the absence of its ruler, which is another instance of the elevated role and higher importance of the ruler in Ara owing to the religious connotations attached to him.

Now, turning towards the purpose of association, for Plato as well as Alfarabi, an association is characterised by the ultimate goal and purpose pursued through it. Although the satisfaction of the basic needs is the goal that gives birth to the human association, they agree that an association for the sole purpose of the fulfilment of basic needs is 'the city of necessity' distinguished from an ideal or perfect city. The end sought by Plato's ideal city is 'happiness':

In finding the city we are not looking to the exceptional happiness of any one group among us but, as far as possible, that of the city as a whole ... we are fashioning the happy city. (Plato 1991:98)

Alfarabi (1985:231), on the contrary, argues that his excellent city is a city 'in which people aim through association at cooperating for the things by which felicity in its real and true sense can be attained'. At first glance, it seems that Alfarabi has borrowed the purpose of association in his city from Plato. However, a closer look shows another picture. The qualification that he has added to 'felicity' points towards the distinction that he makes between true and presumed felicity. In 'The enumeration of the sciences', he (Alfarabi 2011:19) argues that things like honour, pleasure and wealth are mistakenly presumed by some to be felicity without being so. Unlike the presumed felicity, the true felicity can only come in the next life. True felicity is the highest perfection of the human soul 'where it is in no need of matter for its support, since it becomes one of the incorporeal things and of the immaterial substances and remains in that state continuously forever' (Alfarabi 1985:205-207). There are certain actions conducive for the attainment of true felicity which are known to the ruler. The people in the virtuous city of Alfarabi cooperate through association for carrying out those actions under the guidance of the ruler. As a result, they achieve true eternal felicity in the eternal afterlife. Thus, the virtuous city and the virtuous actions performed in it are means for the attainment of the ultimate goal in the afterlife. It seems the reflection of the Islamic principle that those who are pious and spend their short worldly life according to the commands of God would be rewarded with blessings, joy and happiness in the afterlife that would last forever. ${ }^{5}$ Muhammad belonged to the Quraysh tribe based in Mecca. Quran's criticism of their polytheistic religion and overindulgence in worldly gratifications antagonised the Quraysh and they started persecuting the Muslims. The basic purpose of Muhammad's and his followers' hijra (emigration) from Mecca and the establishment of the city-state of Medina was to provide the 5.Quran $29: 64,31: 8-9,16: 32,89: 27-30,13: 23-24$. 
Muslims with a safe environment where they could freely perform their religious obligations and the virtuous actions specified by God through Muhammad that would ensure the ultimate eternal happiness in the afterlife. The Muslims emigrated and forsook their homes, properties, businesses and even families for a greater goal in the afterlife, which set the Islamic principle that the actual purpose of human existence in this world, individually as well as in a group, is not the worldly gains but ensuring the ultimate happiness in the afterlife. Although, with the passage of time, the Muslims who were once a small group of emigrants became a huge, rich and powerful empire, they degraded morally and spiritually. Their rulers, particularly Umayyads and Abbasids, who were criticised for their divergence from the Islamic notions, indulged in sensuous gratification and made the acquisition of pleasure, wealth and power, instead of happiness in the afterlife, their ultimate goal. Alfarabi's emphasis on the happiness in the afterlife as the actual 'felicity' and the real goal of association, most plausibly, is a criticism of the worldliness of these dynasties and a reminder of the Islamic norms and principles.

One of the major distinctions between Plato's and Alfarabi's theory of the state is that while Plato limits his utopia in size, Alfarabi depicts a universal utopia that encompasses the whole inhabitable world. Walzer rightly points out that the inspiration for Alfarabi's universal state does not seem to have come from a Greek source: 'the evidence for thinking in terms of a universal state is rather scarce in Greek literature', and it is also unconvincing to understand Alfarabi's world state as an influence of Alexander and his conquests (Walzer 1985:433). It is, however, important to note that the concept of the world state is not altogether absent in the Greek literature. While early Greek philosophers preferred to press the distinction between the Greeks and the barbarians and professed the superiority of the Greeks, the Stoics opposed the traditional Greek view and argued that all human beings are equal citizens of the world irrespective of their different geographical, racial or linguistic affiliations because they share the common humanity. This Stoic view is commonly known as cosmopolitanism. ${ }^{6}$ It is, however, difficult to argue that Alfarabi's universal state is inspired by Stoics' concept of cosmopolitanism as it cannot be ascertained that this Stoic concept even reached Alfarabi. The introduction of Greek philosophical thought to the medieval Muslim world is owed mainly to the extensive programme of the translation of Greek texts into Arabic that was carried out through the collaboration of Christian and Muslim scholars between the 8th and 10th centuries largely in Baghdad, the seat of the Abbasid caliphate. ${ }^{7}$ As a result of this translation movement, most of the works of Plato, Aristotle and their late Greek commentators had been translated into Arabic by the time of Alfarabi (Black 2011:57). However, as far as we know, there is no evidence that, by the time of Alfarabi, the Stoic text containing the concept of cosmopolitanism was translated

6.For a detailed discussion on cosmopolitanism see Nussbaum 1997; Trepanier and Habib 2011; Lane 2014.

7.For details about the translation movement see Gutas 1998 into Arabic and made available to Alfarabi. Gerard Verbeke (1983) in his famous work, The Presence of Stoicism in Medieval Thought, challenges the traditional approach in which the Stoic influences in the medieval philosophical thought are ignored in favour of Platonic and Aristotelian influences. However, he did not trace the source of Alfarabi's universal state to Stoics' cosmopolitanism. Perhaps the most important indication of Alfarabi's lack of enough conversance with Stoicism is that there is only one instance of a reference to Stoics' philosophy in his corpus. In his short treatise, 'What ought to precede the study of Philosophy', he describes the Stoics as the 'people of the Stoa' whose teachings took place on a porch that was attached to the temple of Athens. He, however, does not even mention 'the name of the actual founder of the Stoic School, Zeno of Citium in Cyprus' (Fakhry 2002:15).

The Alfarabic concept of the world state, most plausibly, has Islamic roots. Islam treats the Muslims as one 'Ummah' (community) irrespective of their various geographical, cultural, linguistic, racial and national affiliations which are, according to the Quran, nothing more than a tool for recognising one another. The Quran asserts, 'Verily, this community of yours is on single community ... We have created you from male and female and made you nations and tribes that you may know one another' ${ }^{8}$ Islam is the bond that unites the Muslims wherever they are into one Ummah. Black (2011) summarises Muhammad's unique transformation of small scattered tribes into one international community:

When Muhammad and his followers forged a new umma, they brought into being at once a sense of Arab nationhood and a new kind of international community. For the first and only time in human history, the nation was transcended at the moment it was created ... Islam preached spiritual brotherhood plus an all embracing law, and universal political control to be achieved ... He [Muhammad] gave a rationale for seeing the Arabs as the chosen people, and giving them a mission to convert or conquer the world. He enabled them to achieve the transition simultaneously from polytheism to monotheism, and from tribalism to nationhood to internationalism. (pp. 9-10)

The expansion of Islam as a religion and as an empire, that the caliphs took seriously, can be seen as an attempt towards the actualisation of a Muslim world state, the rationale for which had been provided by Islam and the prophet. Although the Sunni caliphs conquered the major portion of the known world, they could not rule the 'whole inhabitable world'. Thus, it is not entirely convincing to understand Alfarabi's world state as a reference to the Muslim empire under Umayyad and Abbasid caliphs. The only account of the realisation of a Muslim world state, that was certainly known to Alfarabi and is agreed upon by Sunnis and Shia, is related to Imam Mehdi. There is a consensus among Muslim theologians, as it is supported by multiple ahadith (sayings of the Prophet Muhammad), that Imam Mehdi will revive Islam in its actual form as it was at the time of Muhammad and establish a universal Islamic government over the whole world near the 8.Quran 21:92, 49:13. 
end of time and that he will fill the world with peace and prosperity after it is filled with injustice and tyranny. It is very plausible that by depicting a world state Alfarabi is referring to the promised universal Muslim world state under the rule of Imam Mehdi.

Disunity is certainly a major threat to the city of Plato. He understands economic interests and family loyalties as the possible sources of disunity in his city. To ensure the unity of the city and to neutralise the economic interests and family loyalties, he introduces the concept of communalism: the wives, the children, the parents and the property will belong to all the guardians 'in common' (Plato 1991:95-96, 136). The principle of common parents, wives, children and properties is established to avoid individuality and self-interest, eliminating the sense of 'your' and ' $m y^{\prime}$, and replacing it with 'our'. However, it is important to note that Plato applies the concept of common property and common family to the ruling class only. ${ }^{9}$ It seems that Plato is interested in the unity of the ruling class only, and the working class is ignored altogether. Karl Popper (2002) highlights the issue in the following words:

Plato's best state is based on the most rigid class distinctions ... the problem of avoiding class war is solved, not by abolishing classes, but by giving the ruling class a superiority which cannot be challenged ... the ruling class alone is permitted to carry arms, it alone has any political or other rights, and it alone receives education ... as long as the ruling class is united, there can be no challenge to their authority, and consequently no class war ... the workers, tradesmen, etc., do not interest him (Plato) at all, they are only human cattle whose sole function is to provide for the material needs of the ruling class. Plato even goes so far as to forbid his rulers to legislate for people of this class, and for their petty problems ... the whole problem of preserving the state is reduced to that of preserving the internal unity of the master class ... the communism is confined to the ruling class, which alone must be kept free from disunion ... the stronger the feeling that the ruled are a different and an altogether inferior race, the stronger will be the sense of unity among the rulers. (pp. 51-53)

Alfarabi does not adhere to Plato's concept of communism as, understandably, there could be no place for such innovation in conservative Muslim religion and society. $\mathrm{He}$, in fact, did not need communism to ensure the unity of his city as he had the religion that had served as a unifying force from the very beginning, partly through the Sharia encompassing almost all the aspects of life and partly through the rituals such as circumcision, pilgrimage and communal prayers that instilled a sense of belongingness to the group. However, he does rank order his city in the form of a hierarchy. He compares his city to a living organism in which different organs and parts perform the functions appropriate for them in a coordinated system that is subordinated to the ruling part. He (Alfarabi 1952:113) enumerates five ranks that constitute his city: (1) the most virtuous or excellent who are 'the wise, the intelligent and the prudent in great matters',

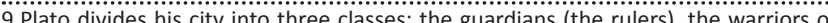
the armed auxiliaries of the ruler(s) and the working class. But as Popper (2002:51) the armed auxilaries of the ruler(s) and the working class. But as Popper (2002:51) argues that because the rulers are, in fact, the wise and old warriors who are promoted from the ranks of the auxiliaries, there are actually only two classes in Plato's city: the armed and educated rulers and the unarmed and uneducated ruled.
(2) the interpreters who include 'orators, the eloquent, the poets, the musicians, the secretaries and the like', (3) the experts including 'the accountants, the geometers, the doctors, the astrologers and the like', (4) the fighting men which are 'the army, the guards and the like', (5) the rich 'who gain wealth in the city, such as farmers, herdsmen, merchants and the like'.

Walzer (1985:436-438) compares the first three ranks of Alfarabi's city to the class of guardians in The Republic that makes the structure of Alfarabi's city identical to the tripartite structure of Plato's city (guardians, the warriors or the auxiliaries, producers). However, the comparison is problematic as Alfarabi's first three ranks include accountants, doctors, musicians, poets and so on, and it is difficult to argue for Plato's willingness to include them in his class of guardians. It is obvious that Alfarabi's first, fourth and fifth ranks correspond to the guardians, the auxiliaries or warriors and the producers of Plato, respectively. Popper's (2002:51) argument that Plato is interested in the rulers only as he 'divides his ruling caste into two classes, the guardians and the auxiliaries, without elaborating similar subdivisions with the working class' is based on the grounds that 'the guardians are no separate caste, but merely old and wise warriors who have been promoted from the ranks of the auxiliaries'. A similar argument for Alfarabi's sole interest in the rulers cannot be made. Neither the fourth nor the second and third ranks of Alfarabi can be argued to be the subdivisions of the ruling class as there is no evidence in Alfarabi that his first rank is composed of the old and wise members of either the fourth rank or the second and the third ranks. On the contrary, it can be argued that the last four ranks of Alfarabi are the subdivisions of the caste of the ruled because the first rank represents the ruling class exclusively. Thus, while Plato is interested in the rulers only as he makes two subdivision of the ruling caste without considering similar subdivisions for the ruled, Alfarabi's subdivision of the ruled into four ranks without considering similar subdivisions for the ruling class can be interpreted as an indication of the importance he, unlike Plato, gives to the ruled in his city.

As mentioned earlier, Alfarabi compares his city with a living organism. As each and every organ of a body is equally important for the health and proper functioning of the body, each and every rank of the city is equally important for the health and proper functioning of Alfarabi's city. Alfarabi (1985:235-237) makes it the duty of the ruler to ensure the removal of any disorder in any part of the city regardless of its position in the hierarchy. Alfarabi (1985:235) acknowledges that people do have natural 'endowments' by birth that are 'unequal in excellence which enable them to do one thing and not another', but, for him, these natural endowments or hereditary lineage are not the sole criteria for inclusion in a specific rank of the city. The voluntary habits such as different arts that one can acquire are equally important. Plato's city is somewhat similar to the Abbasid caliphate in the rigid class distinction and the unchallengeable 
superiority of the ruling class. Because Alfarabi's city can be seen as a protest against the Abbasid caliphate, he could not adhere to Plato's view of class distinction, the unchallengeable superiority of the rulers and the miserable condition of the ruled.

Plato gets rid of the inferior ones and does not allow them into his city: the city takes a start by sending the people over the age of 10 out of the city; deformed and inferior children will be put to death (Plato 1991:139, 220). These measures are designed to obtain a pure specimen for the application of his programme. His scheme of training and education is designed exclusively for the guardians, and the common masses are ignored completely. The rulers' exclusive right to education manifests the superiority that Plato assigns to the ruling class. On the contrary, it also indicates that he is hopeless about the remedial impact of his programme on the imperfect ones. Although Alfarabi makes a distinction between the knowledge of a philosopher and the nonphilosophers, he, nonetheless, seeks perfection for 'all the people of the excellent city', and argues that all of them 'ought to' have the basic knowledge about everything (Alfarabi 1985:277-279). While Plato either excludes or expels the imperfect natures, Alfarabi's policy towards them seems to be that of reformation through the knowledge they can grasp which is religion, the symbolic imitation of philosophy. Undoubtedly, Alfarabi knew that it was the same remedy that had resulted in a revolution and reformed some of the most imperfect natures of the history through the hands of Muhammad, three centuries before him.

\section{Conclusion}

Alfarabi admired Plato and borrowed the idea of the philosopher king from him, but calling his theory of state Platonic seems an inaccurate assessment as it involves overlooking his rich historical context that contains its own unique model of utopia as well as dystopia and a programme for revival. Muslims deem the Prophet Muhammad a perfect ruler and the city-state of Medina, that he established, the perfect state, a utopia. However, the death of Muhammad was followed by sociopolitical degradation of the Muslims owing to the absence of a coherent political philosophy. Alfarabi's theory of the state is a programme for revival, a solution to the peculiar Muslim problem. Not only the problem that Alfarabi deals with, but also his suggested solution to the problem is peculiarly Islamic. Alfarabi was a Muslim philosopher and he did not need to look anywhere else for a solution as he had the example of a perfect city ruled by a perfect ruler in the form of the city-state of Medina ruled by Muhammad and the promised Muslim universal state ruled by Imam Mehdi, a reflection of Muhammad's character, a promised messiah who will revive the Muslim glory. After a careful examination of Alfarabi's theory of the state in light of its historical context, we saw that the ruler of his virtuous city resembles the Muslim perfect rulers and differs considerably from Plato's philosopher king in The Republic in characteristics, functions, source of knowledge and role in the city. In addition to that, eternal felicity in the afterlife as the ultimate purpose of association, the concept of universal utopia and suggesting reformation of the imperfect souls through religious education instead of abandoning them are other factors that identify Alfarabi's theory of state with the Islamic concept of state and distinguish it from that of Plato's The Republic.

\section{Acknowledgement Competing interest}

The authors have declared that no competing interests exist.

\section{Author contributions}

The research was carried out by I.A. under the supervision of Prof. M. Qin.

\section{Ethical consideration}

This article followed all ethical standards for carrying out research without direct contact with human or animal subjects.

\section{Funding}

This research received no specific grant from any funding agency in the public, commercial, or not-for-profit sectors.

\section{Data availability statement}

Data sharing is not applicable to this article as no new data were created or analysed in this study.

\section{Disclaimer}

The views and opinions expressed in this article are those of the authors and do not necessarily reflect the official policy or position of any affiliated agency of the authors.

\section{References}

Alfarabi, 1952, 'Fusul al madani', D. M. Dunlop (transl.), in 'Alfarabi's aphorisms of the statesman', Iraq 14(2), 93-117. http://doi.org/10.2307/4199557

Alfarabi, 1985, Mabadi Ara Ahl al-Madina al-Fadhila, R. Walzer (transl.), Clarendon Press, Oxford.

Alfarabi, 2011, 'The enumeration of the sciences', C.E. Butterworth (transl.), in J. Parens \& J.C. Macfarland (eds.), Medieval political philosophy: A sourcebook, 2nd edn., pp. 18-23, Cornell University Press, Ithaca, NY.

Al-Jabri, A., 2000, Naqd al-aql al-Arabi 3: Arab political reason, The Center for the Study of Arab Unity, Beirut.

Black, A., 2011, The history of Islamic political thought: From the prophet to the present, 2nd edn., Edinburgh University Press, Edinburgh.

Fairahi, D., 2003, Power, knowledge and legitimacy in Islam, Nay Publications, Tehran.

Fakhry, M., 2002, Alfarabi, founder of Islamic Neoplatonism: His life, works and influence, Oneworld Publications, Oxford.

Gutas, D., 1998, Greek thought, Arabic culture: The Graeco-Arabic translation movement in Baghdad and early Abbasid society (2nd-4th/8th-10th centuries), Routledge, London.

Lane, M., 2014, 'Cosmopolitanism', in The birth of politics: Eight Greek and Roman political ideas and why they matter, pp. 215-240, Princeton University Press, Princeton, NJ. https://doi.org/10.2307/j.ctvc7721z.11

Lapidus, I., 1975, 'The separation of state and religion in the development of early Islamic society', International Journal of Middle East Studies 6(4), 363-385. https://doi.org/10.1017/\$0020743800025344

Marmura, M., 2005, Probing in Islamic philosophy: Studies in the philosophies of Ibn Sina, al-Ghazali and other major Muslim thinkers, Global Academic, Binghamton, NY. 
Melamed, A., 2003, The philosopher-king in medieval and renaissance Jewish political thought, Lenn E. Goodman (ed.), State University of New York Press, Albany, NY.

Nussbaum, M., 1997, 'Kant and stoic cosmopolitanism', The Journal of Political Philosophy 5(1), 1-25. https://doi.org/10.1111/1467-9760.00021

Pines, S., 1963, 'Translator's introduction', in Moses Maimonides the guide of the perplexed, University of Chicago Press, Chicago, IL.

Plato, 1991, The Republic, 2nd edn., A. Bloom (transl.), Basic Books, New York.

Popper, K., 2002, The open society and its enemies, Routledge, London, New York.

Rosenthal, E., 1958, Political thought in medieval Islam: An introductory outline, Cambridge University Press, Cambridge.
Strauss, L., 1945, 'Farabi's Plato', in Louis Ginzberg: Jubilee volume on the occasion of his seventieth birthday, pp. 357-393, American Academy for Jewish Research, New York.

Tabatabai, J., 1994, Decline of political thought in Iran, Kavir Publications, Tehran.

Trepanier, L. \& Habib, K. (eds.), 2011, Cosmopolitanism in the age of globalization Citizens without states, University Press of Kentucky, Lexington, KY.

Verbeke, G., 1983, The presence of Stoicism in medieval thought, The Catholic University of America Press, Washington, DC.

Walzer, R., 1985, Alfarabi on the perfect state, Clarendon Press, Oxford.

Walzer, R., 1991, 'Alfarabi', in B. Lewis, C. Pellat \& J. Schacht (eds.), Encyclopaedia of Islam, New edn., vol. 2, pp. 778-781, Brill, Leiden. 